\title{
Pequeña semblanza de Guillermo Díaz-Plaja
}

\author{
Remembering Guillermo Díaz-Plaja
}

\author{
Francisco Abad \\ UNED \\ fabad@uned.es
}

El presente profesor y escritor nació en Manresa (al igual que el historiador Manuel Riu) el 25 de Mayo del año 1909, y murió en Barcelona el 27 de Julio de 1984, a sus 75 años. Fue historiador y crítico de la literatura, ensayista y poeta: ampliamente escritor, y escritor bilingüe en castellano y catalán y de variado registro genérico y temático, según decimos. Mantuvo además una despierta y amplia sensibilidad para su lengua materna - la catalana - y la pluralidad de culturas peninsulares: en varias ocasiones se le vio como posible y magnífico eslabón o enlace entre Castilla y Cataluña: era un conciliador nato. Fue hijo de militar, lo que le llevó a residir en distintas ciudades: según él mismo dice, publica el primer artículo muy tempranamente, en 1924, acaba el bachillerato en Gerona, estudia Filosofía y Letras en Barcelona hasta 1930, y se doctora en Madrid (1931); la tesis — años más tarde publicada como artículo y en folleto- trató de Las teorías sobre la creación del lenguaje en el siglo XVI. En 1932 fue profesor adjunto universitario de Ángel Valbuena Prat, y en 1935 catedrático del Instituto Jaime Balmes de Barcelona.

En el mismo 1935 recibe el Premio del Concurso Nacional de Literatura por su obra Introducción al estudio del Romanticismo español, cuyo texto había surgido de dos cursos monográficos universitarios impartidos no mucho antes. Valbuena lo caracteriza enseguida en tanto «destaca especialmente en el género del ensayo» y procede en gran parte de Eugenio d'Ors y su arte de la glosa; se estima sin embargo en un enjuiciamiento global y a posteriori, que el tono de libre ensayo que define a veces incluso los escritos más académicos del autor, ha podido perjudicar su consistencia estrictamente erudita y filológica; en la franqueza y confianza de una carta privada y manuscrita, don José Manuel Blecua le manifestaba a su amigo Guillermo no sin una punta de malicia: «Después de leer un libro tuyo me voy corriendo a leer los Orígenes del español para salvarme», o sea, para curarse del puro y libre ensayo con la estricta erudición de asunto medieval. Al llegar la guerra civil nuestro autor es ya un hombre, y la carrera de Guillermo Díaz-Plaja, tal como advierte Martín de Riquer, «ha sido fulgurante y se ha ido cimentando en una labor impresa muy considerable»: en efecto Díaz-Plaja fue muy precoz, escri- 
bió sobre la Vanguardia artística de los años veinte y treinta del siglo xx, sobre cine, sobre el diálogo peninsular entre las culturas castellana y catalana, etc. Fue así una persona muy inserta en las circunstancias artísticas, intelectuales y públicas de la España del momento, y más tarde de otros momentos.

Una dedicación continua del autor resultó la de los manuales y libros de texto; no se ha tratado de un trabajo menor y movido nada más que por los intereses materiales; según ha proclamado el propio Riquer, «no hay que olvidar ni menospreciar este aspecto del quehacer de Díaz-Plaja, porque [...] hace de él el mentor y guía literario, en más de un cuarto de siglo, de gran parte de la juventud española, y porque, me consta, ha desvelado y suscitado auténticas vocaciones literarias». Por igual veremos a Francisco Rico valorar esta dedicación a la composición de manuales.

Guillermo Díaz-Plaja organizó además una muy amplia Historia General de las Literaturas Hispánicas (1949-1968) encabezada con el conocido estudio de Menéndez Pidal acerca de los rasgos caracterizadores de la literatura española («Caracteres primordiales de la literatura española»), y con otro estudio suyo acerca de la historiografía de esa literatura, que es lástima no resultase más demorado y consistente, aunque parece que intentaba tal ampliación; asimismo estuvo al frente de una también voluminosa Antología mayor de la literatura española (1958-1960), antología difundida luego por igual en edición abreviada de bolsillo. Del mismo modo hizo volúmenes antológicos equivalentes para las letras hispanoamericanas: la visión del autor fue siempre muy comprehendedora de todo lo hispánico, que englobaba así sus varias lenguas y tradiciones culturales.

Poco más tarde del libro en torno al Romanticismo, Díaz-Plaja compuso un extenso manual — que está entre los acaso más logrados u serios libros suyosacerca de La poesía lírica española (1937), quizá por desdicha (creemos) nunca retomado luego en cuanto tal. En 1941 Menéndez Pidal escribía en carta a don Guillermo y en referencia a este libro suyo: «Leo con gusto su La poesía lírica española. Al caos habitual en los manuales sustituye $\mathrm{Vd}$. una ordenación clara de la extensa materia, juicios guiadores, ejemplos poéticos breves significativos. A la división por siglos generalmente estéril, le da Vd. un sentido por medio de los epígrafes generales que dentro de ella establece». Vemos a don Ramón rechazar otra vez la parcelación estricta por centurias que ya tenía hecha al hablar del lenguaje del xvi, y alabar el procedimiento del prof. Díaz-Plaja de tener en cuenta hechos de concepto («epígrafes generales») en el interior de las centurias. Estamos ante el buen positivismo analítico pidalino. De su lado Marañón manifestaba a propósito de la misma Historia de la lírica cómo era un libro «extraordinario de claridad y de bien arreglada sabiduría. [...] Es opinión de mero aficionado pero muy sincera».

Sucesivamente don Guillermo compuso el volumen El espíritu del Barroco (1940); las monografías Modernismo frente a Noventa y Ocho (1951), El poema en prosa en España (1956), Las estéticas de Valle Inclán (1965), Estructura y sentido del Novecentismo español (1975), así como otras sobre García Lorca —en la que alude bien orientado a «Poeta en Nueva York» y sobre Juan Ramón Jiménez; etc. Estas obras son probablemente las que mayor repercusión académica han tenido; tal repercusión se ha manifestado a veces en forma de disenti- 
miento, disentimiento tampoco en todas las ocasiones bien justificado. Sumemos entre lo más académico el texto El estudio de la literatura (1963), sin duda su Memoria de opositor a cátedra, y digamos asimismo que el análisis sobre el poema en prosa despertó por su «entidad» e «importancia» el entusiasmo de Vicente Aleixandre.

Pero don Guillermo fue autor también de volúmenes de ensayos como Poesía y realidad (1952), Defensa de la crítica (1953), El reverso de la belleza (1956), El estilo de San Ignacio y otras páginas (1956), Cuestión de límites (1963), ... El buen estudioso de la filología leerá con gusto algunas de estas páginas, todas ellas - y otras más - reunidas en su libro de conjunto Ensayos sobre literatura y arte (1973); por igual es bien sugerente el libro Las lecciones amigas (1967). Otro volumen de conjunto es el que se rotula Obras Selectas (1972), en el que aparecen páginas representativas de las varias facetas del autor: filólogo, poeta, viajero, periodista, ...

Lo mismo que tempranamente por el cine, Guillermo Díaz-Plaja se interesó mucho a lo largo de su vida por el teatro, género sobre el que dirigió otra obra enciclopédica de diferentes autores: El teatro. Enciclopedia del arte escénico (1958), y al que dedicó sucesivos escritos ya desde su juventud.

Pero se trató además de un escritor que compuso ensayo de amplia temática, libros de viajes, obra lírica, páginas periodísticas, ... De entre sus volúmenes de ensayo podemos destacar la belleza incluso moral de los Discursos para sordos (1968), y el Tratado de las melancolías españolas (1975).

De carácter testimonial y autobiográfico resultan necesarios por lo menos sus dos libros Memoria de una generación destruida (1966), y Retrato de un escritor (1978), que en realidad son textos que han de considerarse como de la bibliografía sobre el autor; por igual puede ilustrar sobre la vida del autor (y sobre la de otros profesores) la selección póstuma de cartas dirigidas a él que se han publicado. El volumen al que hemos aludido Ensayos sobre literatura y arte contiene páginas y pasajes sugerentes, por ej. sobre «las características radicales de la literatura española», páginas en las que insiste también al subrayar «la existencia de varias realidades lingüísticas y culturales en la Península», por lo que «hay literaturas catalana, gallega, vasca, además de la de Castilla . [...] Consideremos pues lo español a la manera de un conjunto sinfónico». El presente volumen incluye asimismo indicaciones y programas pedagógicos.

En todo caso la obra publicada de Guillermo Díaz-Plaja es extensísima y muy variada, con tono en general bien pedagógico según decimos, bien de erudición o libre ensayo, bien estrictamente de creación literaria o periodística. Como ocurre en ocasiones con los autores que han publicado bastante, y acaso asimismo por caídas que a veces ocurren en la asertividad expositiva, creemos que Díaz-Plaja está algo infravalorado en sus logros escritos de profesor e investigador. No lo ha hecho así como queda anunciado Francisco Rico, quien tiene dicho: «En la destrozada escuela de la posguerra [...] los manuales de Díaz-Plaja — con los de José Manuel Blecua y apenas más- fueron un privilegio para no pocos». 
Enumeramos ahora obras reseñables suyas, entre otras desde luego: Vanguardismo y protesta en la España de hace medio siglo, Barcelona, Asenet, 1975 [agrupa artículos juveniles]; Introducción al estudio del Romanticismo español, Madrid, Espasa-Calpe, 1936; La poesía lírica española, Barcelona, Labor, 1937; Las teorías sobre la creación del lenguaje en el siglo XVI, Zaragoza, Tip. «La Académica», 1939; Hacia un concepto de la literatura española, col. «Austral» de Espasa-Calpe, 1942; Federico García Lorca, Buenos Aires, Kraft, 1948, reimpreso en «Austral»; Modernismo frente a Noventa y Ocho, Madrid, Espasa-Calpe, 1951 (con reimpresión posterior, de la que no se ha corregido alguna errata desorientadora en cronología); El poema en prosa en España, Barcelona, Gustavo Gili, MCMLVI; De literatura catalana. Estudis $i$ interpretacions, Barcelona, Selecta, 1956; Juan Ramón Jiménez en su poesía, Madrid, Aguilar, 1958; «Introducción histórica», en El teatro. Enciclopedia del arte escénico dirigida por él mismo, Barcelona, Noguer, 1958, págs. 9-59; El estudio de la literatura, Barcelona, Sayma, 1963; Las estéticas de Valle Inclán, Madrid, Gredos, 1965; Ensayos elegidos, Madrid, Ediciones de la Revista de Occidente, 1965; Memoria de una generación destruida, Barcelona, Aymá, 1966; Las lecciones amigas, Barcelona, Edhasa, 1967; Poesía junta (19411966), Buenos Aires, Losada, 1967; Soliloquio y coloquio, Madrid, Gredos, 1968; Discursos para sordos, Madrid, Magisterio Español, 1968; Los paraísos perdidos, Barcelona, Seix Barral, 1970; Obras Selectas, Barcelona, AHR, 1972; Ensayos sobre literatura y arte, Madrid, Aguilar, 1973; Estructura y sentido del Novecentismo español, Madrid, Alianza, 1975; Tratado de las melancolías españolas, Madrid, Sala Editorial, 1975; Retrato de un escritor, Barcelona, Pomaire, 1978 (incluye en Apéndice la bibliografía del autor); El combate por la luz. La hazaña intelectual de Eugenio d'Ors, Madrid, Espasa-Calpe, 1981; Querido amigo, estimado maestro. Cartas a Guillermo Díaz-Plaja (1929-1984), Universitat de Barcelona, 2009. Podemos añadir un manual para el Preuniversitario de «Literatura española contemporánea» que alguna vez tenemos mencionado.

Entre los escritos dedicados a nuestro autor figuran estos: A. VALBUENA, «Díaz-Plaja (Guillermo)», en Enciclopedia Universal Ilustrada EuropeoAmericana. Suplemento 1936-1939. Primera Parte; M. DE RIQUER, «Discurso de contestación» en La dimensión culturalista en la poesía castellana del siglo XX, Discurso de recepción del académico D. GUILLERMO DÍAZPLAJA, Madrid, RAE, 5 de Noviembre de 1967, págs. 155-194 (incluye la bibliografía del autor); A. ZAMORA VICENTE, Historia de la Real Academia Española, Madrid, Espasa, 1999; JOSÉ-CARLOS MAINER, «El ensayista bajo la tormenta: Guillermo Díaz-Plaja (1928-1941)», en su La filología en el purgatorio, Barcelona, Crítica, 2003 [nuestra percepción de algunos hechos profesionales de este volumen no coincide siempre y exactamente con la de este autor y buen amigo: a veces es más sombría, y en otras ocasiones resulta algo más favorable, por ej. respecto quizá a don Guillermo]. 